\title{
CHRISTELIKE HOËR ONDERWYS EN DIE OPLEIDING VAN ONDERWYSERS.
}

\section{1.}

Een van die belangrikste take wat die Universiteit moet verrig, is die opleiding van onderwysers.

Die geskiedenis van die Universiteite leer ons hierdie belangrike ieit. Dic oudste inrigtings vir hoër onderwys het reeds as doel gehad die opleiding van aanstaande lerare. Gedurende die Middeleeue het die Universiteite selfs 'n diploma uitgereik aan persone wat hulleself deur studie bekwaam het om onderwys te gee, die sgn. .,jus ubique docendi," die reg on orals onderwys te gee. Nou is dit wel waar dat die ou Universitêre opleiding van onderwysers beperk was: die jongmanne is net onderrig in 
die wetenskappe as sodanig sonder dat hulle daarby ook opleiding ontvang het in die metode van onderwys, en die jongmanne is eintlik net opgelei vir die meer gevorderde, d.w.s. die middelbare en die hoër onderwys. Hierdie taak is nog nooit deur Universitêre inrigtings prysgegee nie: manne vir die middelbare en hoër onderwys is vir die werk opgelei aan die Universiteite. Die opleiding was akademies-wetenskaplik en nie professioneel-opvoedkundig nie. Maar die oorgang van 'n suiwer akademiese tot ' $n$ akademiese en 'n professioneel-opvoedkundige opleiding hoef niemand te verwonder nie. Daar is wel mense wat van die standpunt uitgaan dat die taak van 'n Universitêre inrigting bloot akademies-wetenskaplik is, maar so 'n opvatting klop nie met die geskiedenis nie. Die Universiteit het deur al die eeue heen altyd 'n professionele karakter getoon. En die professionele opleiding van die onderwyser bly ' $n$ inherente deel van die taak van die Universiteit.

Ook in Suid-Afrika leer die geskiedenis ons dat die Universitêre inrigtings hulle bewus was van die taak en nog is. So byvoorbeeld het die Raad van die Victoriakollege, tans die Universiteit van Stellenbosch, reeds in die jare 1905 en 1906 besliste pogings aangewend om 'n leerstoel vir die Opvoedkunde ingestel te kry met die oog op die opleiding van onderwysers vir middelbare skole. Maar dit was eers in 1909 dat die Raad in sy pogings geslaag het, sodat die Stellenbosche inrigting sinds 1910 onderwysers kon oplei.. Dieselfde reg is toe ook verleen aan die Kaapstadse inrigting. In die Vrystaat is daar reeds in 1909 'n professor in die Opvoedkunde benoem en is daar onderwysers aan die GreyUniversiteitskollege opgelei.

$\mathrm{Na}$ die totstandkoming van die Unie van die vier Suid-Afrikaanse Kolonies in 1910 is daar 'n stap verder gedaan deurdat vanaf 1913 voorsiening gemaak is deur die Minister van Onderwys vir die opleiding van onderwysers vir middelbare skole aan al die toe bestaande Universitêre kolleges. Aan die opgeleide onderwysers is tocgeken die Unie-eersteklasonderwysersertifikaat $(0.1)$.

Van hierdie praktyk is sindsdien nog nie afgewyk nic. Daar het wel in 1922 'n verandering ingetree, waardeur die Universitêre inrigtings verplig was om vanaf 1923 'n eie diploma in te stel vir die onderwysers wat aan die inrigtings opgelei is. Die nuwe sertifikaat is, altans in die geval van die Universiteit van Suid-Afrika, genoem die „Hö̈r Onderwysdiploma" (H.O.D.).

Vandag is die toedrag van sake so dat al die Suid-Afrikaanse Universitêre inrigtings onderwysers oplei: sommige bepaal hulle streng by die opleiding van onderwysers vir die middelbare skole, terwyl die 
neerderheid hulle werksaamhede ook uitgestrek het tot die opleiding van onderwysers vir laerskole en ook vir besondere skole.

Die Universiteit is in menige opsig 'n ideale plek vir die opleiding van onderwysers. Dit kan aan die jong mense die stof sowel as die metode van onderwys gee. Dit het die wetenskaplike vakmanne on die stof te onderwys maar ook om die metode van onderrig te onderwys: die vakman is presies op hoogte van die stof en die metode van sy wetenskap. Aan die Universiteit is daar ook 'n breër opleiding vir die onderwysers, omdat hulle in kontak kom met jongmense van allerlei studierigting. Dit bewaar die aanstaande onderwyser nie alleen van 'n enge professionalisme nie, maar plaas hom as werker in die ry van ander werkers en sy gebied in die ry van die wetenskappe. Die Opvoedkunde word so 'n erkende Universitêre wetenskap.

\section{II}

Die Potchefstroomse Universiteitskollege vir Christelike Hoër Onderwys het dan ook hierdie werksaamheid van 'n Universitêre inrigting van die staanspoor af uitgeoefen. Reeds voor hierdie inrigting ingelyf is in die Universiteit van Suid-Afrika, het dit voorsiening gemaak vir die opleiding van onderwysers vir middelbare skole, en wel vir die Unie-O.1. $\mathrm{Na}$ sy inlywing het dit net die taak voortgegaan en mettertyd twee professore in die opvoedkunde in sy diens gehad: die een 'n ere-professoraat toegeken aan die hoof van die plaaslike Normaalkollege, en die ander 'n voltydse professoraat sinds Februarie 1925 beklee deur die ondergetekende. Die P.U.K. vir C.H.O. voorsien vanaf 1923 in die opleiding van jongmense vir die H.O.D., oorspronklik suiwer vir middelbare skole, maar sinds 1935 is dic H.O.D. vervang deur 'n nuwe diploma, die Universiteits-Onderwysdiploma (U.O.D.), oorspronklik ingestel vir alle soorte onderwysers (laer en middelbaar) maar aan hierdie inrigting uitsluitend beperk tot die opleiding vir middelbare skole.

Die P.U.K. handhaaf dus nog steeds die eeue-oue tradisie om onderwysers op te lei vir die middelbare (en moontlik hoër) onderwys. Die kwekelinge ontvang opleiding in die suiwer akademiese vakke maar ook in die professionele vakke-die opleiding is volledig. Die P.U.K. verkeer egter in 'n baie gunstige posisie deurdat dit die heelhartige steun ontvang van die plaaslike Onderwyserskollege. Daardeur ontvang die U.O.D.studente 'n uitstekende opleiding: akademies, opvoedkundig-wetenskaplik, professioneel. Die P.U.K. en die P.O.K. vul mekaar so aan in die opleiding van onderwysers, want die studente van die P.O.K. ontvang weer op hul beurt hul akademiese vorming aan die P.U.K. Ek dink ek het reg om te beweer dat nerens in Suid-Afrika daar 'n gunstiger geleentheid 
gebied word vir die opleiding van die aanstaande onderwysers, sowel vir laer as vir middelbare skole.

Nou kom daar ten slotte nog een uiters gewigtige saak by. Dic P.U.K. vir C.H.O. is uiteraard gedwing om baie, nie volledige aandag te gee aan die opleiding van onderwysers. Al sou dit geen taak van die Universiteit gewees het om onderwysers op te lei nie, dan nog sou die P.U.K. dit moes gedoen het. Dit lê in die aard van die inrigting.

Die P.U.K. is 'n inrigting vir Christelike Hoër Onderwys. Dit het meer as 'n bloot akademiese taak. Dit het ook 'n sendingstaak: dit moel die lig van Gods Woord gebruik by die ondersoek en die dosering van die wetenskap. Die P.U.K. is 'n draer, en 'n draer is altyd 'n opvoeder. As die roeping waarvoor die P.U.K. hom gestel het, tot verwesenliking moet kom, dan moet dit ook jongmense kweek wat die beoefening van die Christelike wetenskap en onderwys tot hul lewenstaak gemaak het. Die P.U.K. moet onderwysers oplei! Nou wil ek nie daarmee beweer dat ander universitêre inrigtings in ons land nie ook hierdie taak het nie-ek wens dat almal dit tot taak wou stel-, maar ek wil dit met al die krag van my woord vaslê dat die P.U.K. met sy eie, selfstandige karakter, geroepe is om onderwysers op te lei, en wel Christelik Nasionale onderwysers vir die behoefte van ons Christelik Nasionale volk tot die eer van God en tot die redding en die opbou van ons Christelik Nasionale Afrikanervolk!

Potchefstroom.

J. CHR. COETZEE. 